\title{
LUGARES PÚBLICOS COMO POTENCIALIDADES: UMA LEITURA URBANA DO CENTRO HISTÓRICO DE SÃO PAULO
}

\author{
PUBLIC PLACES AS POTENTIAL: \\ A URBAN READING OF HISTORY CENTER OF SÃO PAULO
}

Lilian Dazzi Braga Rupf*

Eugenio Fernandes Queiroga**

\begin{abstract}
RESUMO
Este trabalho propõe um ensaio de leitura urbana a fim de apreender relações entre o espaço urbano produzido e as vivências cotidianas no Centro Histórico de São Paulo, através da observação empírica do presente como espessura que remete ao passado e futuro. Ao contrário de alguns discursos, não há uma redução de sua vida pública, o que há é uma mudança nesta, que adquire maior complexidade: novos usos e dinâmicas ocupam seus lugares públicos. Hoje a área central tem como herança um rico sistema de espaços livres que protagoniza grandes momentos da vida pública paulistana; estes, independentemente do perfil e da apropriação dos usuários, são fortemente utilizados.

Palavras-chave: Lugar público. Sistema de espaços livre. Centros históricos.
\end{abstract}

\begin{abstract}
This work proposes essay of urban reading in order to grasp relations between the urban space and the everyday experiences in the Historical Center of São Paulo, through the empirical observation of your present as thickness refers to the past and its future. Different from what is presented in some discourses there is no reduction in his public life; instead, there is a change in it, becoming more complex with dynamic new uses occupying their public places. Today the downtown has a rich legacy as a system of free spaces that already staged great moments in the public life of São Paulo society, these independent of characteristics and appropriation of its members are heavily used.
\end{abstract}

Keywords: Public place. System of open spaces. Historic centers.

\section{INTRODUÇÃO}

A função das cidades, historicamente, é ser lugar de trocas, convergências, concentração e confrontos. Sua configuração espacial está sob constante ação dos mais

\footnotetext{
* Arquiteta e urbanista pela Universidade Federal do Espírito Santo (UFES). Mestranda em Paisagem e Ambiente pela Faculdade de Arquitetura e Urbanismo da Universidade de São Paulo (FAUUSP). Avenida São Luís, 192, ap. 1.411, 01046-000, República, São Paulo, SP, Brasil.

lilian.braga@usp.br

** Arquiteto e urbanista, mestre, doutor e livre-docente pela Faculdade de Arquitetura e Urbanismo da Universidade de São Paulo (FAUUSP). Professor associado da FAUUSP. Rua do Lago, 876, Cidade Universitária, São Paulo, SP, Brasil. queiroga@usp.br
} 
diversos agentes e sua materialidade é dimensão ativa que influencia nossas ações. Milton Santos (2012a) descreve a importância da proximidade entre indivíduos coexistindo nos espaços da cidade, cujo território compartido e suas intensas inter-relações proporcionam múltiplas formas de comunicação.

Pode-se definir como urbanidade a qualidade do urbano que propicia a copresença entre diferentes na experiência do urbano. Paulo Rheingantz $(2012$, p. 136) convida a entender a urbanidade como experiência "[...] que não tem sua origem nas pessoas nem no ambiente construído, que se produz na relação entre ambos, um produto das relações entre humanos e não humanos". A urbe é condição de convívio, interação - e a esfera da vida pública propicia a ocorrência dessas ações em sua potencialidade máxima. É necessário relevar a importância de estudos que buscam compreender a forma urbana da cidade, com as lógicas e dinâmicas de seus espaços de uso público, possibilitando contribuições para a sua qualificação de modo a potencializar a esfera de vida pública:

[...] é a cidade, como forma espacial, também, o principal espaço de resistência aos processos hegemônicos, do estabelecimento da cultura e das oportunidades de exercício da cidadania. Importa, pois, compreender a produção e apropriação das formas em movimento se se deseja qualificar não apenas as formas, mas a construção do lócus que contribua para o estabelecimento da condição cidadã de seus vivenciadores [...] (MACEDO et al., 2012, p. 22).

Este trabalho propõe um ensaio de leitura urbana a fim de apreender relações entre o espaço urbano produzido e as vivências cotidianas no Centro Histórico' de São Paulo. Através da observação empírica do presente como espessura que remete ao passado e ao futuro, leem-se potencialidades que, num cotidiano apenas vivenciado, talvez não pudessem ser reconhecidas. Ferrara (2000, p. 124) identifica a leitura da experiência cotidiana como além de um simples ver físico, um ver inteligente, "[...] a que se opõe o cotidiano como continuidade perceptiva". Na leitura urbana há produção de descontinuidade:

Produzir essa descontinuidade é desfazer a linearidade e ler por saltos, revelando o imprevisto recorte inovador que permite que se aproxime duas ou mais imagens, antes desconexas. Revela-se um sentido novo, insuspeito, mas não escondido, pois ele é, antes de tudo, produzido. Essa descontinuidade preserva a surpresa ante a cidade de todos os dias. Essa surpresa é, sem dúvida, visagem no sentido de partir de um estímulo visual, mas como é alusivo, é miragem de sugestão de sentidos que vivem à margem do visual inicial e podem ser apreendidos, se resgatados pela observação.

\footnotetext{
Entre os tipos de centralidades urbanas possíveis (econômica, funcional, regional e locais), chama-se "Centro Histórico", ou "Centro Tradicional", aquele que abrigou o núcleo original da fundação da cidade, sendo, historicamente, locais de convergência de trajetos, encontros e trocas comerciais, de atividades religiosas, de lazer, políticas, culturais e financeiras. Os Centros Tradicionais são referenciais simbólicos das cidades, de suas identidades, tanto para cidadãos como para visitantes, e, por excelência, agregadores de diversidades. Adota-se como Centro Histórico de São Paulo a área conhecida como Centro Velho, primeiro núcleo de ocupação, e Centro Novo, primeira expansão urbana, contidos nos distritos administrativos da Sé e República.
} 
A leitura são montagens de fragmentos de imagens do presente e de sentidos imaginários nutridos e atrelados à sua memória, ao seu passado. É tarefa da leitura urbana apreender mediações, formas de relação do homem com o espaço cotidiano da cidade, através de suas representações, identificando-as e interpretando, uma estratégia de legibilidade da experiência cotidiana.

O recurso da fotografia possibilita a leitura de exploração visual imediata, a captura de descontinuidades, relacionadas ao cotidiano, que propiciam a percepção da cidade através da comparação de seus fragmentos espaciais e experienciais. Para Ferrara (2000), não é possível ler a cidade em seu conjunto, pois é fenômeno orgânico em constante transformação. Devem-se ler seus fragmentos de forma comparativa, a fim de fazer emergir semelhanças e diferenças. A heterogeneidade da urbe pelos seus diversos ritmos, formas e experiências de seus usuários é responsável pela fragmentação de lugares com particularidades, "[...] construídos a partir de relações e experiências socialmente produzidos":

Dessa forma, a imagem dinamizada pelo imaginário encontra, na leitura, uma atividade cognitiva que parte da visualidade icônica para atingir as tramas criadas pelo uso, porém, essa montagem de imagens preenchidas de sentidos imaginários é autorizada logicamente pela dimensão viva e orgânica do cotidiano, responsável pela dimensão fenomenológica da cidade. Assim, a montagem que concretiza a leitura não é arbitrária, mas lógica, embora sem prescrições, códigos, normas ou gramática. (FERRARA, 2000, p. 126).

O Centro Histórico da cidade de São Paulo passou, ao longo do século XX, por significativas mudanças na forma urbana, nos padrões sociais e econômicos, implicando novos usos e dinâmicas de seus lugares públicos. A mudança dos interesses políticos e econômicos e o deslocamento de grande parte da classe alta e das atividades nobres para novos bairros durante a segunda metade do século $X X$ implicaram a imagem de deterioração e degradação do centro. Apesar de deixar de ser protagonista, a área central sempre esteve em pautas de discussões de políticas governamentais, ocorrendo, em maior ou menor grau, investimentos em infraestrutura urbana.

Diferente do que se apresenta em alguns discursos, não há redução de sua vida pública, mas sim mudanças, adquirindo maior complexidade e transformando-se de uma maioria elitizada a uma maioria popular. Esse novo caráter não elimina o contato entre diferentes estratos socioeconômicos - desde os altos cargos jurídicos ou do mercado da bolsa de valores, aos funcionários públicos, estudantes, turistas, comerciantes e consumidores do comércio ambulante -, que convivem e compartiIham, cotidianamente, variadas instâncias espaciais.

A tolerância à diversidade sempre foi característica do Centro Histórico. Ruth Cardoso (2001) evidencia que o centro da cidade abriga grandes diferenças de modo de vida e renda. Seu atual caráter, predominantemente comercial e de serviços, torna-o esvaziado à noite, permitindo que grupos marginalizados o utilizem. Essa tolerância 
dificilmente ocorreria em bairros residenciais. Os espaços públicos do centro e, destacadamente, suas ruas, têm pertencimento coletivo para a maioria dos que o frequentam e retornam a seus bairros e para quem ali encontra abrigo.

\section{A DIMENSÃO DO LUGAR PÚBLICO}

Tendo como referência os estudos de Milton Santos, adota-se, neste trabalho, a sua definição de espaço como instância social em intrínseca relação com as demais instâncias: econômica, político-institucional e cultural-ideológica. $\bigcirc$ espaço contém e é contido pelas demais instâncias. De essência social, é definido como um conjunto de objetos geográficos somado à sociedade, suas ações e seus processos. Todos os processos - econômicos, ideológicos ou institucionais - incluem o espaço e adquirem expressão territorial. (SANTOS, 2012b).

Essas intrincadas relações entre forma física e ação social revelam-se no conceito de forma-conteúdo de Santos (2012b): em movimento dialético, as formas físicas estão em constante alteração, de acordo com o movimento social em um dado momento. Pode-se dizer que a forma, em sua qualidade de forma-conteúdo, é permanentemente alterada, e que o conteúdo ganha nova dimensão ao encaixar-se na forma. A ação é condizente com a forma que a contém. Assim, os processos apenas ganham inteira significação quando corporificados (SANTOS, 2012b).

Milton Santos apresenta o espaço - para finalidade de análise e prática metodológicas - como totalidade de relações (espaço total), composto por categorias internas (subespaços). Define o lugar como categoria interna ao espaço, assim como o território e a paisagem. O lugar é próprio da dimensão espacial de cotidianidade, dimensão do espaço total, em constante mudança, onde se experienciam e se apreendem relações de materialidade, movimento social e tempo.

No lugar - um cotidiano compartido entre as mais diversas pessoas, firmas e instituições - cooperação e conflito são a base da vida em comum. Porque cada qual exerce uma ação própria, a vida social se individualiza; e porque a contiguidade é criadora de comunhão, a política se territorializa, com o confronto entre organização e espontaneidade. O lugar é o quadro de uma referência pragmática ao mundo, do qual the vêm solicitações e ordens precisas de ações condicionadas, mas é também o teatro insubstituível das paixões humanas, responsáveis, através da ação comunicativa, pelas mais diversas manifestações da espontaneidade e da criatividade. (SANTOS, 2012a, p. 218)

Para essa reflexão, adota-se, aqui, o conceito de lugar público de Eugenio Queiroga (2012) - baseado nos estudos de Milton Santos e Jürgen Habermas - definido como lócus da esfera de vida pública: "[...] todo aquele em que se estabelece a esfera públi-

2 Queiroga (2012) desenvolve, também, o conceito de esfera pública geral, como aquela que abarca toda a vida em público, seja ela política ou não, incluindo as ações cotidianas de convívio em público, voluntário ou involuntário, que se constituem como parte da vida pública. 
ca". Desse modo, os lugares públicos não são restritamente propriedades públicas e se estabelecem, com frequência, na combinação de espaços tanto de propriedade privada como pública, lugares de caráter urbano e público, onde a vida coletiva se desenvolve.

Nos lugares públicos, há o "embate" com o outro - mesmo que inconscientemente - no contato entre diferentes classes, interesses e objetivos, nas mais diversas situações, como no deslocar-se das calçadas, no mercado, na biblioteca, na praça.

Embora crescente, o discurso do esvaziamento dos lugares de uso público está distante de ser regra em nossa realidade. A dimensão pública é lugar de manifestações políticas, festas populares e diversas apropriações, numa sociedade cada vez mais complexa, em constante processo de transformação.

Faz-se necessário compreender, diante dessa complexa dialética espacial, como esses espaços, projetados ou não, podem gerar contextos - em suas conjunturas sociais, políticas, econômicas e culturais - que possibilitem a plena manifestação da vida pública.

\section{O PRESENTE COMO ESPESSURA QUE REMETE AO PASSADO}

Este é um breve panorama das intensas e sucessivas alterações na configuração da forma urbana dos lugares públicos do Centro Histórico de São Paulo durante o século $X X$, conformando seu atual sistema de espaços livres.

Em seus três primeiros séculos de existência, a cidade de São Paulo concentrava, na sua pequena colina de base triangular, suas principais funções. Já no final do século XIX, após a chegada da ferrovia, antigas chácaras, ao redor do triângulo histórico, foram loteadas para receber novas demandas da capital, que crescia com a economia cafeeira. Em 1892, foi inaugurado o viaduto do Chá, unindo a colina à nova área de expansão, ao conhecido Centro Novo (figura 1). (TOLEDO, 2007).

A cidade iniciou o século XX recém-expandida, de sua colina histórica para além do Vale do Anhangabaú. Entre 1890 e 1914 houve intensa imigração europeia. Segundo Toledo (2007, p. 181), "[...] com os imigrantes vieram novas técnicas de construir e a cidade foi reconstruída integralmente, disso resultando uma nova imagem: a metrópole do café".

A antiga cidade de barro transformou-se: novas avenidas e espaços públicos foram criados, urbanizados e ajardinados; abriram-se bulevares arborizados e ruas coloniais foram realinhadas a fim de apagar o aspecto rural, não condizente com seu crescente status; a cidade ganhou ares europeus e os parques Anhangabaú e Dom Pedro II foram inaugurados (figura 2). Apesar de ser espaço das elites, o centro apresentava, também, o novo setor médio (profissionais liberais, funcionários públicos e comerciantes) e o setor popular (imigrantes operários de fábricas, ex-escravos, carregadores, vendedores ambulantes):

A São Paulo antiga era dominada pela visualidade de base e horizontal: era a imagem das grandes extensões percorridas a pé, no passeio protegido pelas árvores. O verde coloria o percurso e impunha-se à visão, tornando mais íntimo o espaço 
e aproximando a cidade da escala humana. Fazia parecer próximo o que na realidade era distante, revertendo a horizontalidade e aproximando o longínquo ponto de fuga. Nada abafa a escala humana, ao contrário, tudo agasalhava, desde as residências que, envolvidas nos seus jardins, ofereciam-se à admiração dos olhares curiosos, até as árvores que, na rua eram o limite que, ao mesmo tempo, protegia e assinalava o espaço, definindo as grandes artérias, ou cobria o andarilho que, na sua caminhada, decidisse parar e observar ou, simplesmente, admirar. (FERRARA, 2000, p. 134).

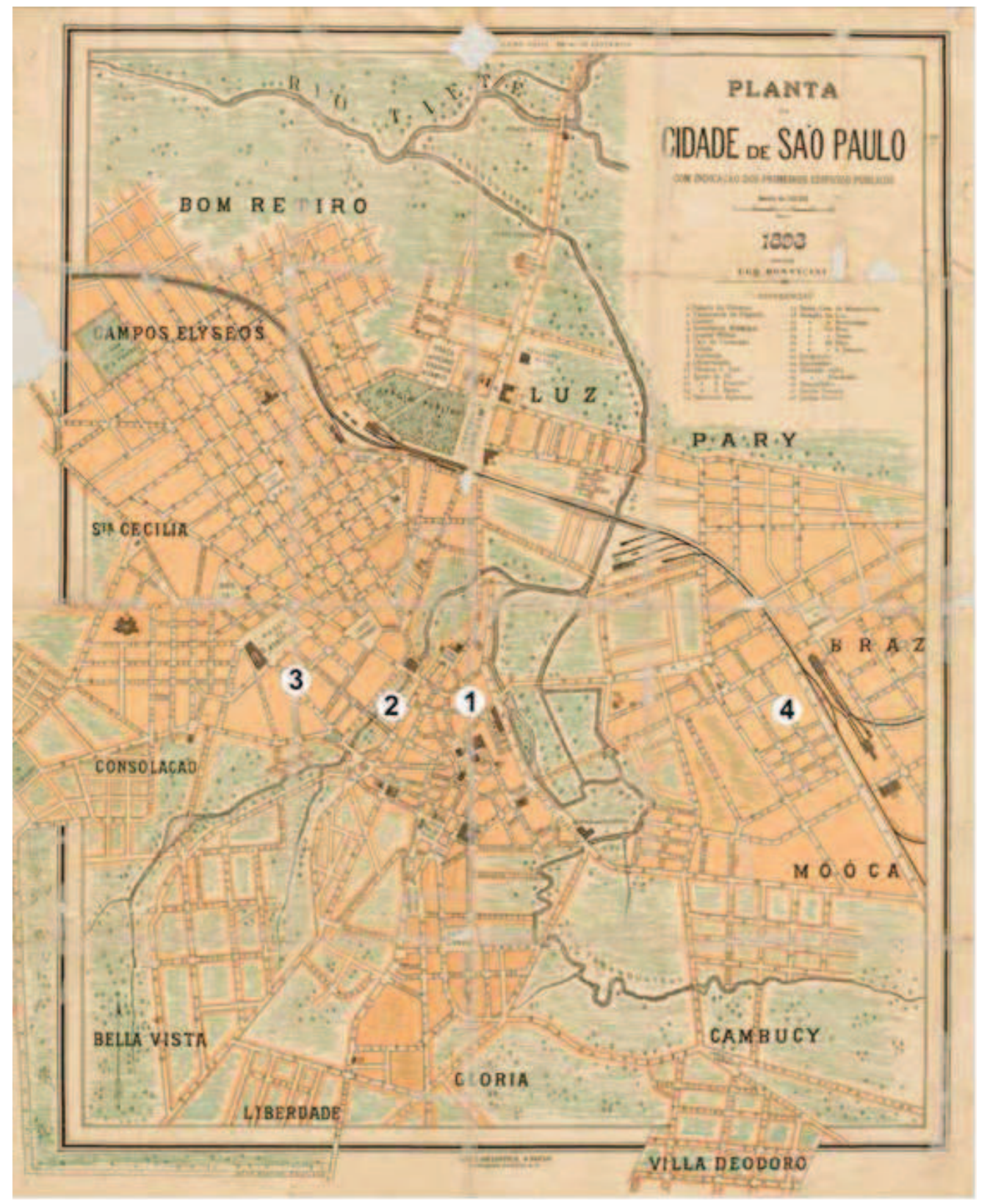

Figura 1 1) Colina-Centro Velho; 2) Viaduto do Chá; 3) Centro Novo; 4) Bairros industriais junto à ferrovia. Fonte: Acervo cartográfico digitalizado do Arquivo Público do Estado de São Paulo (APESP) 


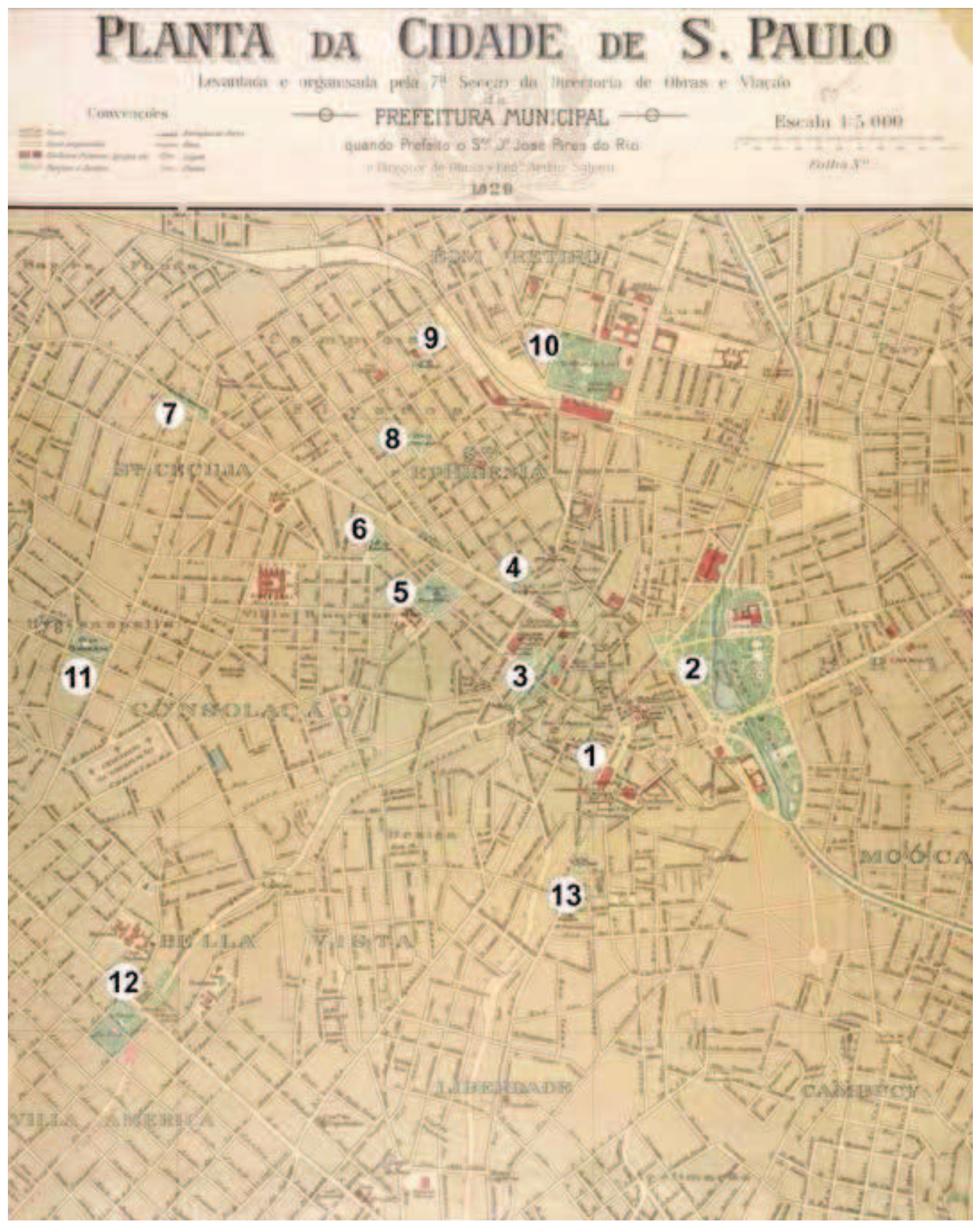

Figura 2 1) Praça da Sé; 2) Parque Dom Pedro II; 3) Parque do Anhangabaú; 4) Largo do Paissandu; 5) Praça da República; 6) Largo do Arouche; 7) Praça Marechal Deodoro; 8) Praça Princesa Isabel; 9) Largo do Coração de Jesus; 10) Jardim da Luz; 11) Praça Buenos Aires; 12) Parque Paulista e Belvedere; 13) Largo da Liberdade.

Fonte: Prefeitura Municipal de São Paulo/Acervo cartográfico digitalizado da Biblioteca Nacional (BN Digital)

A descrição de Ferrara demonstra uma qualidade espacial não mais recorrente nos espaços da atual cidade, condizente com a escala do corpo humano, base e referência dos deslocamentos na cidade, possibilitando o andar com certo conforto, que potencializava a pausa, a permanência e o eventual encontro (figura 3). 


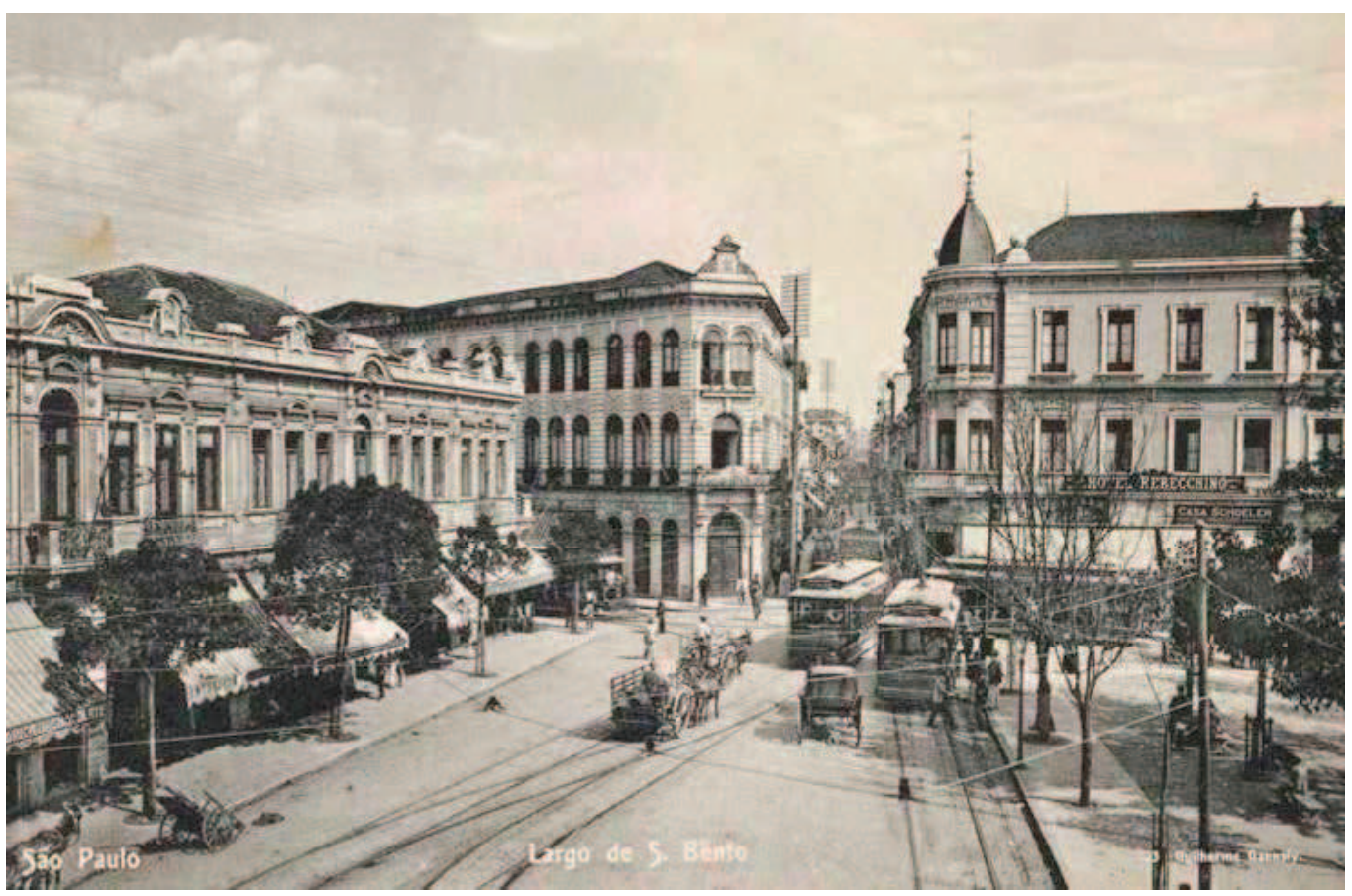

Figura 3 Largo de São Bento - 1911

Imagem: Guilherme Gaensly

Fonte: Acervo iconográfico digitalizado do Arquivo Público do Estado de São Paulo (APESP)

Segundo Reis Filho (2004, p. 141), em 1930 a cidade era centro de uma grande e rica região produtiva e a base da sua economia já não era apenas a produção agrícola, mas também a industrial: "[...] a cidade impunha-se como um polo de produção, de distribuição industrial e de comércio". A necessidade de melhor infraestrutura, de transportes e de maior aproveitamento do solo no centro levou-o a reconstruir-se - dos bondes às primeiras linhas de ônibus. A área antiga do centro manteve certo caráter europeu e o Centro Novo possuía características norte-americanas.

Na década de 1930, ocorreu o início da implantação do Plano de Avenidas de Francisco Prestes Maia. A estrutura viária aberta conformou um esquema radioconcêntrico, com avenidas radiais, o primeiro e o segundo anéis perimetrais ao centro (o segundo completado apenas na década de 1960). (REIS FILHO, 2004). O plano anunciou a predominância das intervenções viárias, a priorização do fluxo e circulação de veículos automotivos nos posteriores planos de ordenação e o crescimento da cidade.

São Paulo chegou à metade do século XX como metrópole industrial, causando grandes fluxos de migrações internas no país em direção à cidade, aumentando-a perifericamente e iniciando a formação de uma região metropolitana. Sua área central, com destaque para o chamado Centro Novo, pulsava como o mais importante espaço cultural e intelectual da cidade, com sua Cinelândia, diversificadas galerias comerciais e restaurantes. Vias foram abertas e alargadas, onde grandes edifícios se instalaram, com estilo norte-americano. Praças foram criadas e remodeladas com características de cidade moderna. 
No século passado, houve mais uma mudança de escala da cidade, que passou de um perfil eminentemente industrial para o de metrópole terciária, centro financeiro e de negócios. A partir da década de 1960, São Paulo atendeu ao mercado regional como polo central de uma região metropolitana, ao redor do qual cresceram outros núcleos e outras regiões metropolitanas (REIS FILHO, 2004). Com o crescimento territorial, estruturaram-se novas centralidades, em consonância com o deslocamento de moradia e trabalho das classes de maior renda para o quadrante sudoeste da cidade. Um novo centro se estruturou ao longo da avenida Paulista, e, posteriormente, na avenida Faria Lima. Já nos anos 1990, conformou-se uma nova área de concentração empresarial, na avenida Engenheiro Luís Carlos Berrini. (FRUGOLI JR., 2000).

A diminuição de investimentos no Centro Tradicional justificou-se pela sua alta densidade, saturação, congestionamentos, polvição, envelhecimento arquitetônico e tecnológico. Essa mudança de área de investimento gera espaços ociosos e vagos, sem a devida manutenção. Os espaços públicos e edifícios do centro passaram a abrigar outros tipos de atividades econômicas, na maior parte populares, ocorrendo, posteriormente, a retomada de atividades administrativas e culturais.

Logo se iniciou uma série de políticas ${ }^{3}$ que buscavam a revalorização da área central, combatendo sua degradação física e decadência econômica, alterando, substancialmente, sua configuração morfológica. Foram inauguradas as linhas Norte-Sul e Leste-Oeste do Metrô (década de 1970) e reconfigurados grande número de seus espaços livres, com execução de obras viárias visando a condições de macroacessibilidade do automóvel, estruturas de vias expressas articuladas a elevados, pontes e viadutos, terminais e corredores de ônibus. (NAKANO; CAMPOS; ROLNIK, 2004).

A integração entre diversos modais de transporte, a oferta de comércio especializado, serviços e instituições, geravam constante e intenso fluxo de pedestres. Em 1976, foi inaugurado o sistema de ruas pedestrianizadas, que liga o chamado Centro Velho (colina histórica) ao Centro Novo (primeira expansão da cidade). A grande acessibilidade através de transporte coletivo também contribuiu para o caráter popular dos comércios e serviços que ali se estabeleceram. (NAKANO; CAMPOS; ROLNIK, 2004).

Entre os programas e projetos ${ }^{4}$ que ainda estão sendo implantados, buscando a revalorização econômica da área central, destacam-se, a partir da década de 1990, a transferência de repartições públicas, implantação de centros culturais ligados às artes e a abertura de centros universitários como importantes geradores de fluxo de pessoas que passaram a usufruir e permanecer nos lugares públicos do centro. Merecem destaque,

A gestão do prefeito Olavo Setúbal (1975-1979) propôs um plano de revitalização para a área, marcando o início de uma série de políticas que buscavam a revalorização da área central.

4 Destaque para o Programa Piloto de Ordenação da Paisagem da Área Central: Eixo Sé-Arouche (1991); projetos de restauração e reprogramação de usos de edifícios subutilizados para usos culturais: Centro Cultural Banco do Brasil (2001), Teatro Municipal, Biblioteca Mario de Andrade, Mercado Municipal (2004), Estações Júlio Prestes (1999) e da Luz; retorno de órgãos públicos para a área central: edifício Martinelli (1979), Palácio das Indústrias (1992), edifício Matarazzo (2004). 
também, novos lançamentos imobiliários ${ }^{5}$, que apontam a retomada de investimentos do setor imobiliário residencial na região.

\section{O PRESENTE COMO ESPESSURA QUE REMETE AO FUTURO}

Com a mudança de padrão de consumo e a efetiva popularização de seus espaços, o caráter polar do Centro Histórico de São Paulo permanece. Congrega ampla rede de transporte público viário e metroviário, que gera intenso fluxo de circulação de pessoas, grande número de comércio e serviços e importante porcentagem de empregos. De acordo com dados do Ministério do Trabalho e Emprego (MTE) 6 , em 2010 a subprefeitura da Sé ${ }^{2}$ continha 16,91\% dos empregos formais da cidade, maior porcentagem de empregos em comparação às demais subprefeituras do município de São Paulo. É necessário ressaltar que esses dados não incluem os empregos da Administração Pública no Município, que correspondem à grande porcentagem dos empregos formais no centro.

Ainda de acordo com dados da Prefeitura de São Paulo ${ }^{8}$, no mesmo período a subprefeitura da Sé possuía 3,83\% da população do município, demonstrando a grande população flutuante que permanece, durante o dia, utilizando infraestrutura e serviços no horário comercial. Segundo Vargas e Castilho (2006), a importância econômica de um centro como esse vai além das transações comerciais e financeiras: está na qualidade da infraestrutura existente e no patrimônio construído ao longo dos anos, com grande capital investido.

Do ímpeto incessante de crescimento e modernização de uma cidade que almejava ares europeus e, posteriormente, norte-americanos, a área central tem como herança um considerável sistema de espaços livres, composto por bulevares, calçadões para pedestres, praças, largos, jardins e galerias (figura 4). A São Paulo antiga, descrita por Ferrara (2000), possuía esses espaços como lugares do coletivo e do exercício da alteridade. Mesmo muitas vezes descaracterizados, tais lugares não perdem seus significados em favor da funcionalidade dos deslocamentos.

A incorporadora Setin está comercializando cinco novos empreendimentos habitacionais na área (avenidas São João, Brigadeiro e São Luís, rua Genebra e praça da República) com previsão de entrega a partir de dez. 2014.

6 Dados do MTE. Relação Anual de Informações Sociais (RAIS). Elaboração: Secretaria Municipal de Desenvolvimento Urbano (SMDU) - Departamento de Estatística e Produção de Informação (Dipro). Disponíveis em: $<$ http://www.nossasaopaulo.org.br/observatorio/regioes.php?tema $=11$ \&indicador $=52$ \&regiao $=6>$. Acesso em: 26 ago. 2014

7 A Subprefeitura da Sé é composta pelos seguintes distritos administrativos: Bela Vista, Bom Retiro, Cambuci, Consolação, Liberdade, República, Santa Cecília e Sé.

8 Dados de Tabela elaborada pela SMDU - Dipro. Com base nos dados do Instituto Brasileiro de Geografia e Estatística (IBGE): Censos Demográficos 1950, 1960, 1970, 1980, 1991, 2000 e 2010; SMDU/Dipro - Retroestimativas e Recomposição dos Distritos para os anos 1950, 1960, 1970 e 1980. Elaboração: Dipro. Disponíveis em: <http://infocidade.prefeitura.sp.gov.br/htmls/7_populacao_recenseada_1950_10491.html>. Acesso em: 26 ago. 2014 . 


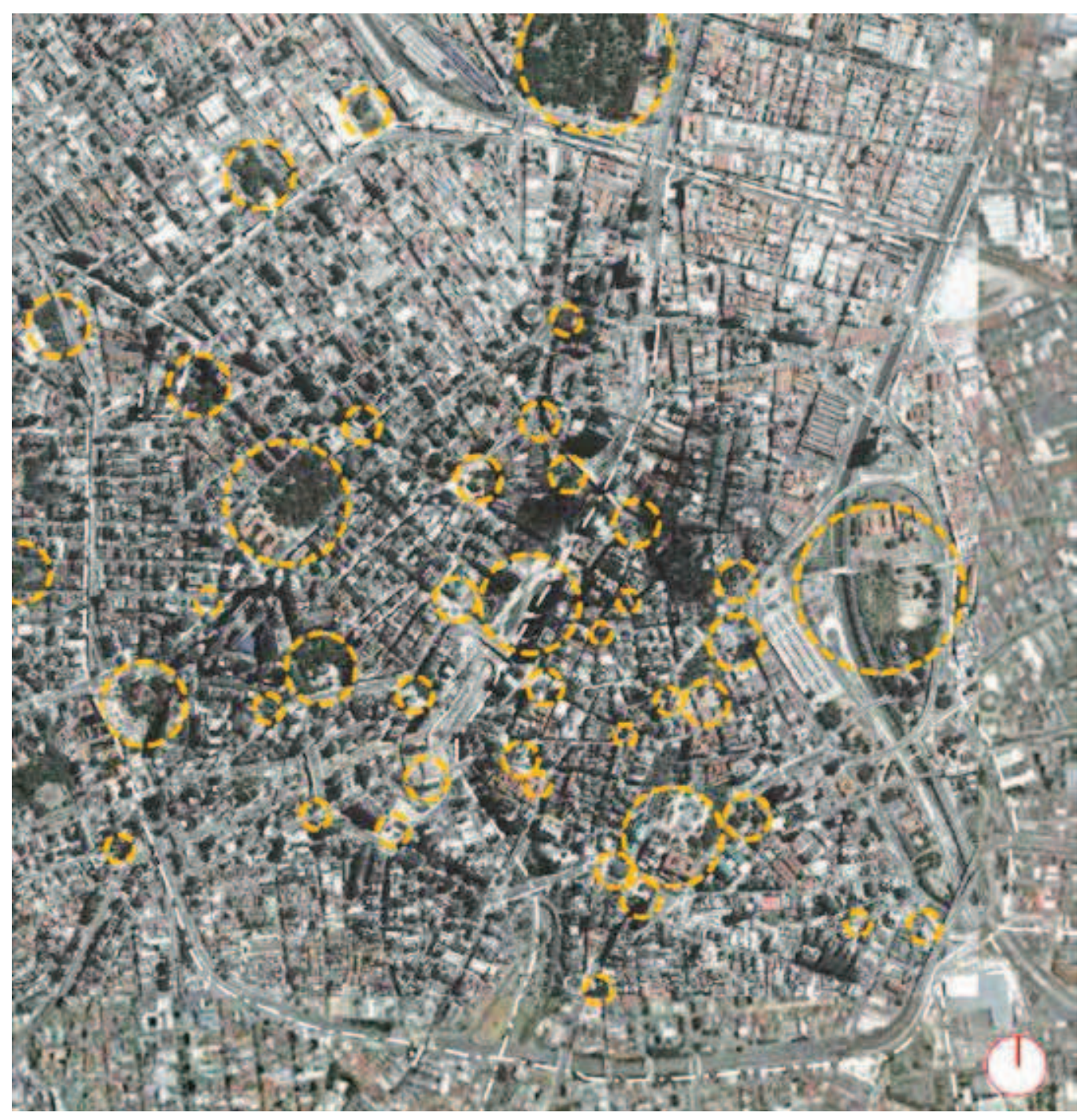

Figura 4 Representação da proporção de espaços públicos no Centro Histórico de São Paulo. Intervenção de Lilian Dazzi Braga Rupf sobre imagem aérea do Google Earth - 2014.

Hoje, o Centro Histórico da cidade pode ser descrito pela visualidade de grandes planos verticais, em sobreposição a uma história que deixa vestígios de seu estreito traçado colonial, marcado por edificações ecléticas mescladas a imponentes edifícios (figuras 5, 6 e 7). Largas avenidas abertas para o crescente fluxo de automóveis não apresentam mais arborização e ajardinamento como práticas recorrentes, que agregavam qualidade à escala do indivíduo.

Muitos de seus lugares públicos foram descaracterizados, tornaram-se ilhas viárias, foram gradeados ou simplesmente abandonados pela administração pública, ficando sem manutenção. Ao mesmo tempo, constata-se que o diverso sistema de espaços livres da área central se encontra ativo, dissolvido em um dia a dia rotulado pela necessidade de deslocamentos rápidos e falta de tempo, impessoalidade e perda da vida pública (figuras 8 e 9). 


$$
\frac{1 n}{I}
$$




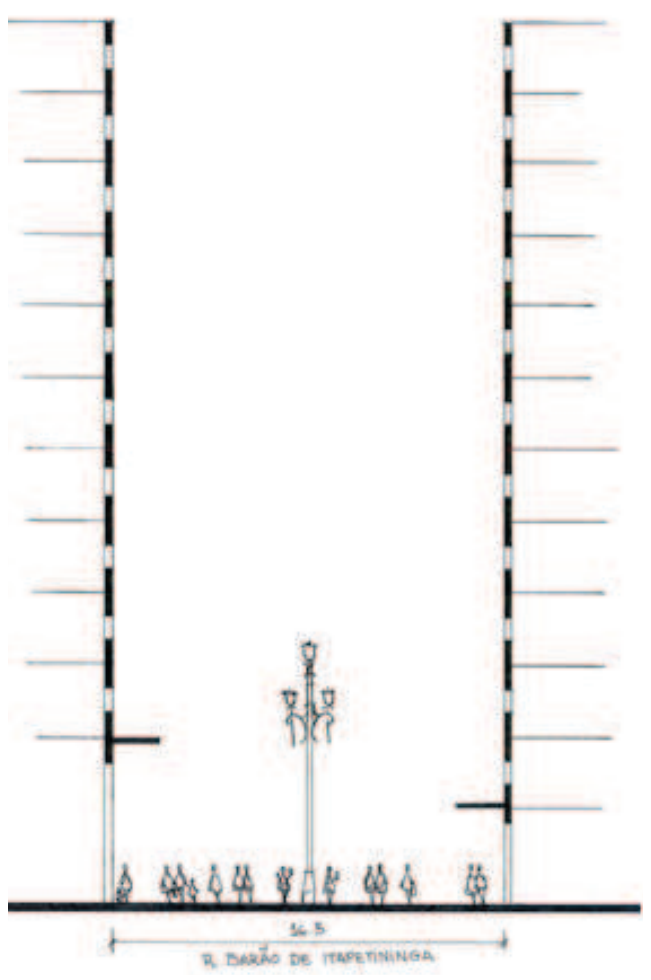

Figura 7

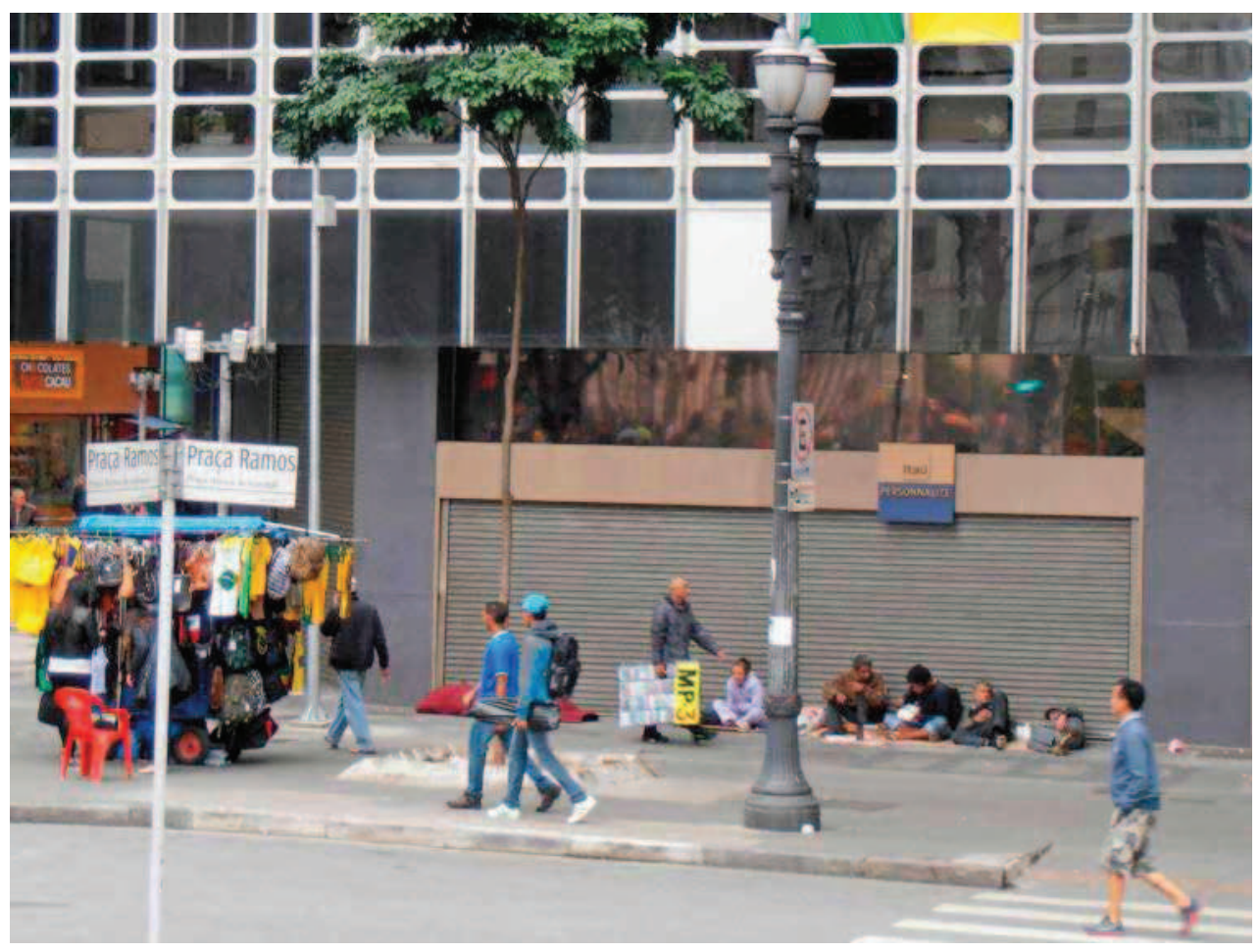

Figura 8 Praça Ramos de Azevedo.

Foto: Lilian Dazzi Braga Rupf - 2014 


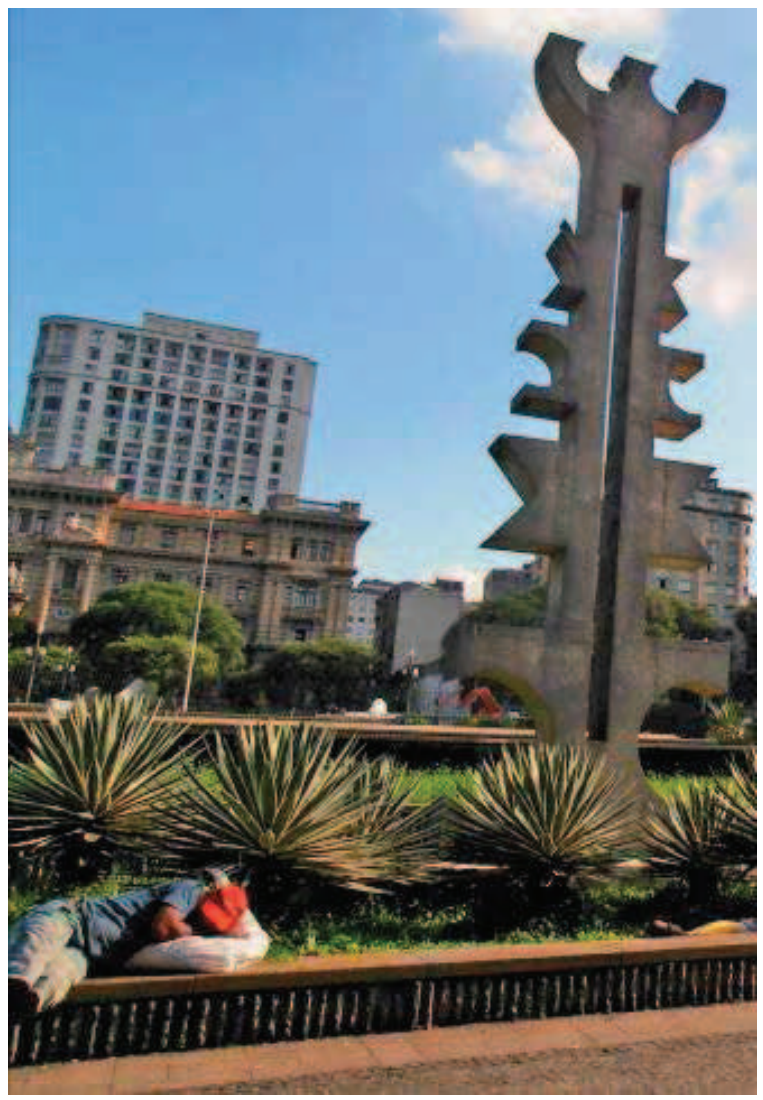

Figura 9 Praça da Sé

Foto: Lilian Dazzi Braga Rupf - 2013

Com extensos calçadões de pedestres e restrições de circulação de veículos que tornam em parte inacessível o uso do automóvel, priorizando o transporte público, o centro impõe o caminhar. Para deslocar-se no Centro Histórico, em maiores ou menores distâncias, não restam muitas alternativas: é necessário utilizar o tatear dos passos por seus lugares públicos. Uma caminhada pelo centro (mesmo imposta por necessidade) desvela a experiência do urbano, expõe ao contato com diferentes, à copresença, a desigualdades e conflitos.

No Centro Histórico, a escala humana se confronta com a verticalidade e a monumentalidade de construções que são símbolos da memória paulistana; suas espacialidades são, muitas vezes, inóspitas e carentes de qualidade ambiental, mas também repletas de gratas surpresas. Ao percorrer seu lugares, é surpreendente quando se descobre caminhos alternativos por curiosas galerias comerciais; ouve-se o barulho das fontes em meio às grandiosas árvores da praça da República e música próximo à galeria Olido; depara-se com a criatividade de artistas de rua em frente ao Theatro Municipal ou no largo de São Bento; descobre-se um pequeno café ou preciosa loja no calçadão de pedestres ou se surpreende quando, ao caminhar da praça da República à praça da Sé, constata-se a longa distância percorrida sem ser percebida. $O$ simples passar quase se transforma em uma pausa, mesmo pequena. Pausa para olhar vitrines, para um café ou lanche; pausa para observar (ou fotografar) cantores de rua, performances, conflitos, manifestações individuais ou coletivas (figuras 10 a 15). 


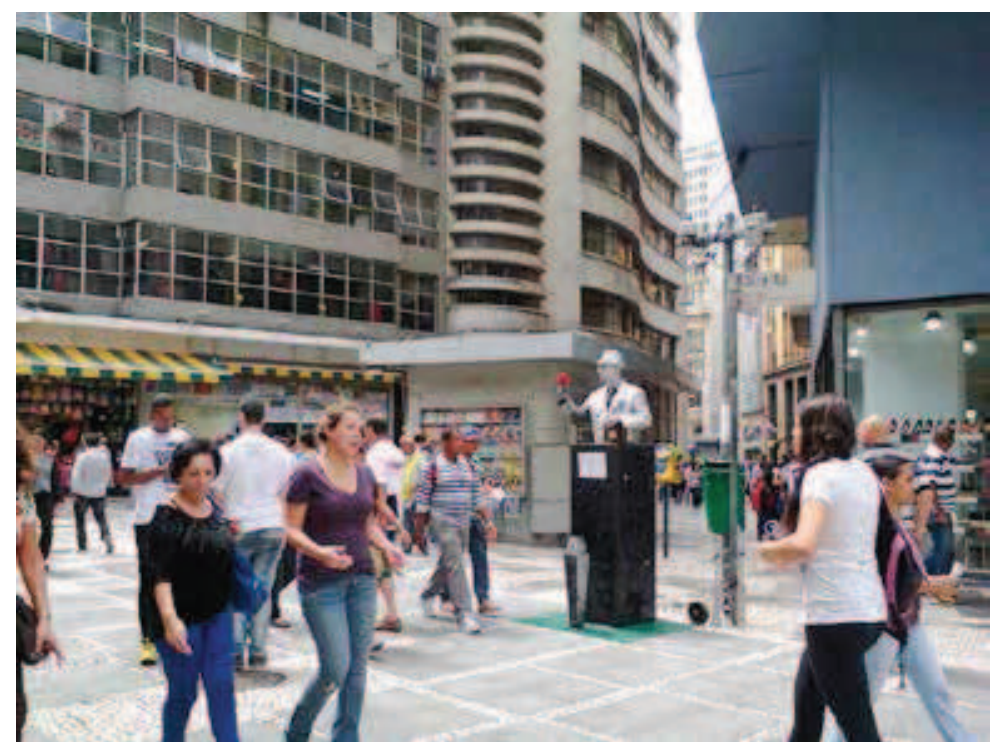

Figura 10 Artista de rua na

Rua Direita.

Foto: Lilian Dazzi Braga Rupf 2014

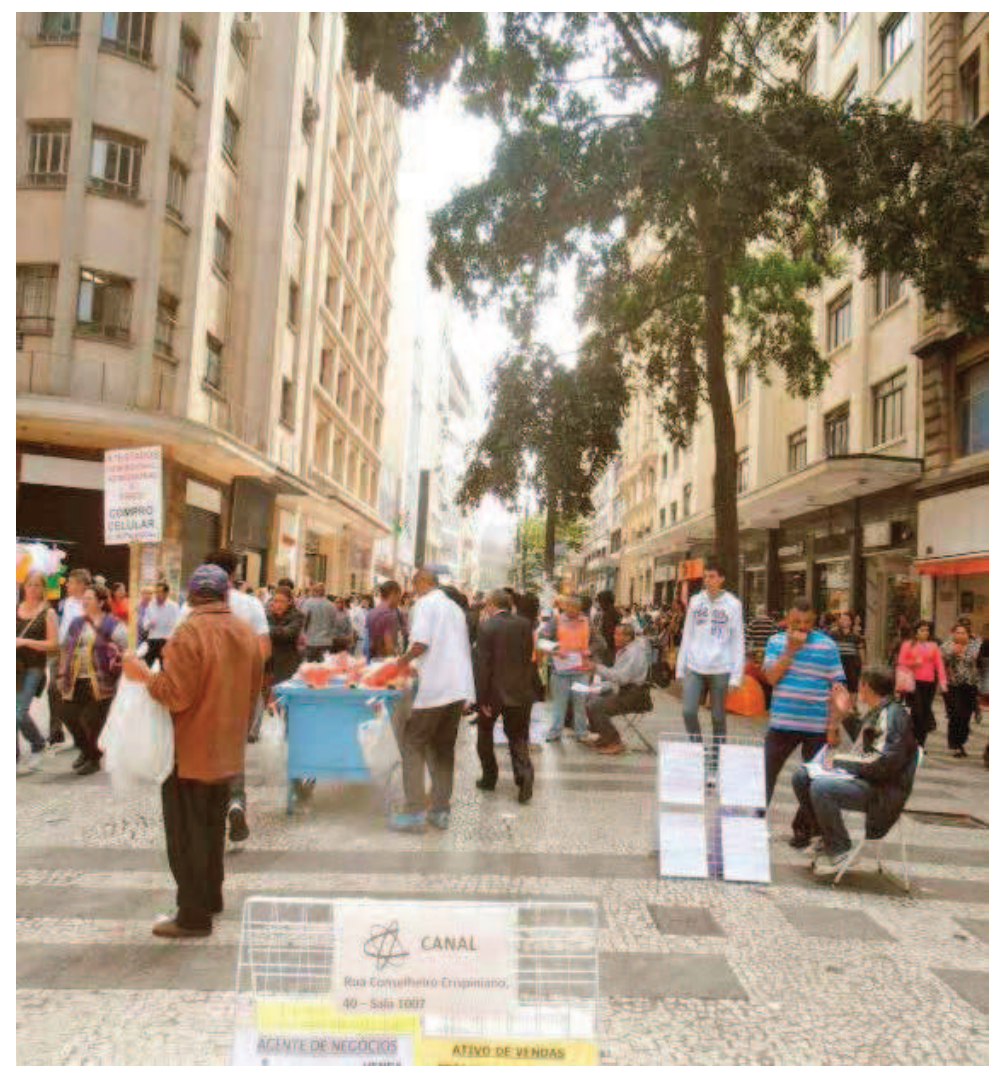

Figura 11 Comércio de

ambulantes na rua Barão de Itapetininga.

Foto: Lilian Dazzi Braga Rupf 2014

A complexidade da vida pública no centro de São Paulo se dá por sua história social, política e econômica, por seu significado simbólico e funcional para a cidade. Deve-se, também, à diversidade de espacialidades encontrada em seus lugares públicos (igrejas, teatros, centros culturais, bibliotecas, instituições, lojas, escritórios, residências e ocupações devido à luta por moradia) - que, com tão diversas funções, propicia tão diversas apropriações de espaços. 


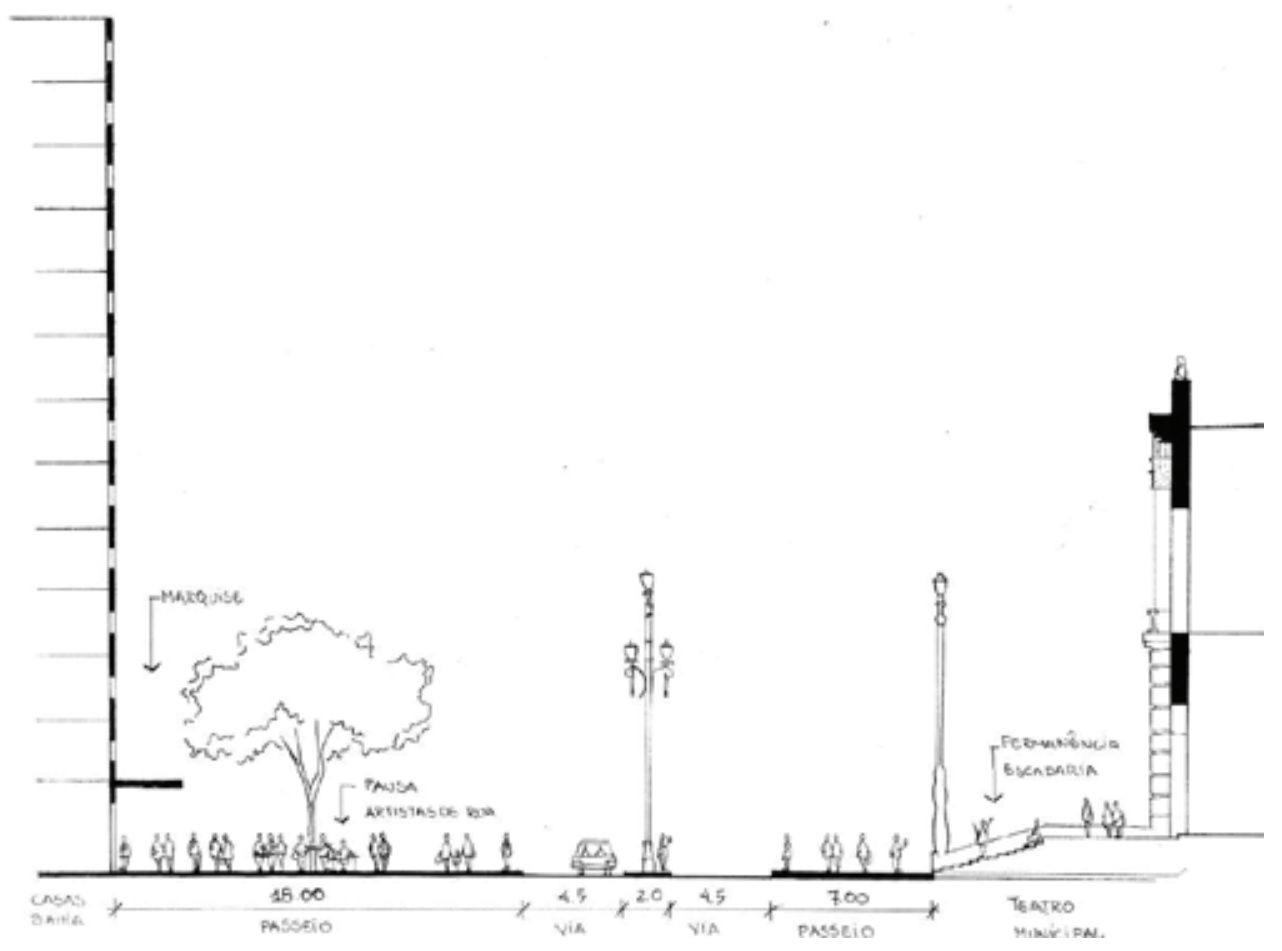

Figura 12 Corte esquemático - Praça Ramos de Azevedo, em frente ao Theatro Municipal. Desenho: Lilian Dazzi Braga Rupf - 2014

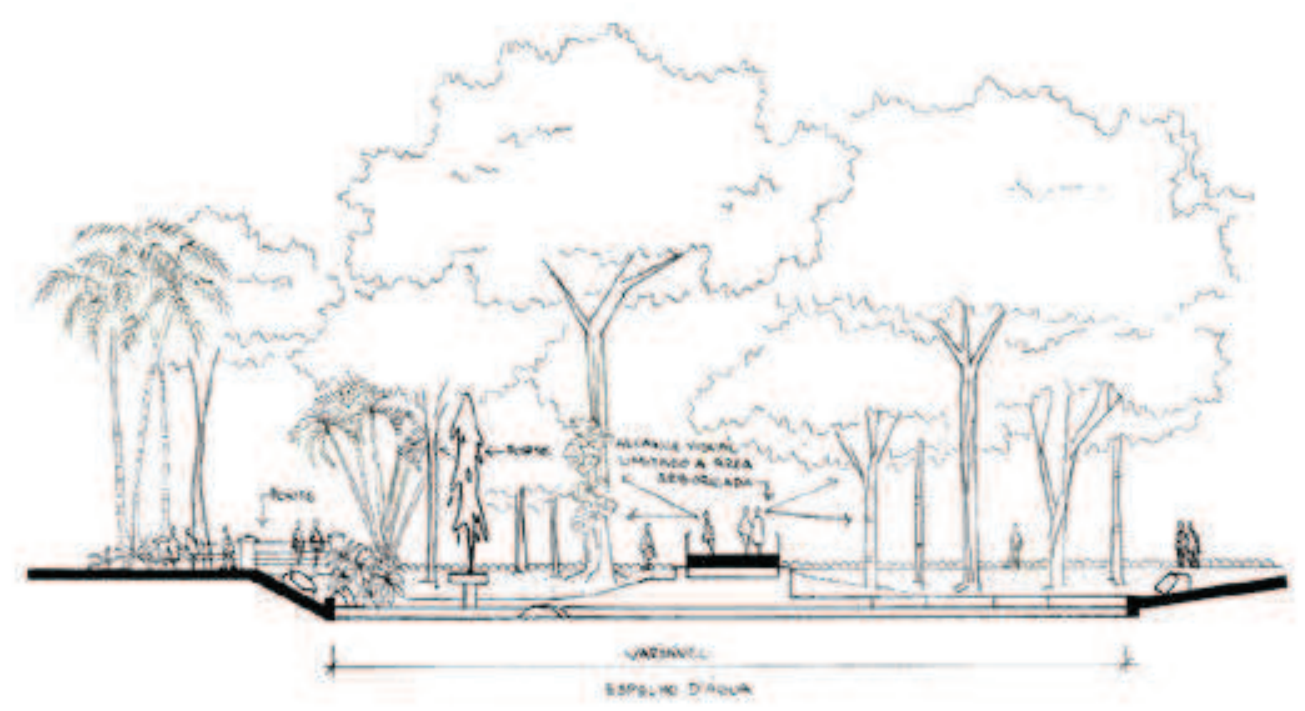

Figura 13 Corte esquemático - Praça da República, fontes e espelhos d'água.

Desenho: Lilian Dazzi Braga Rupf - 2014 


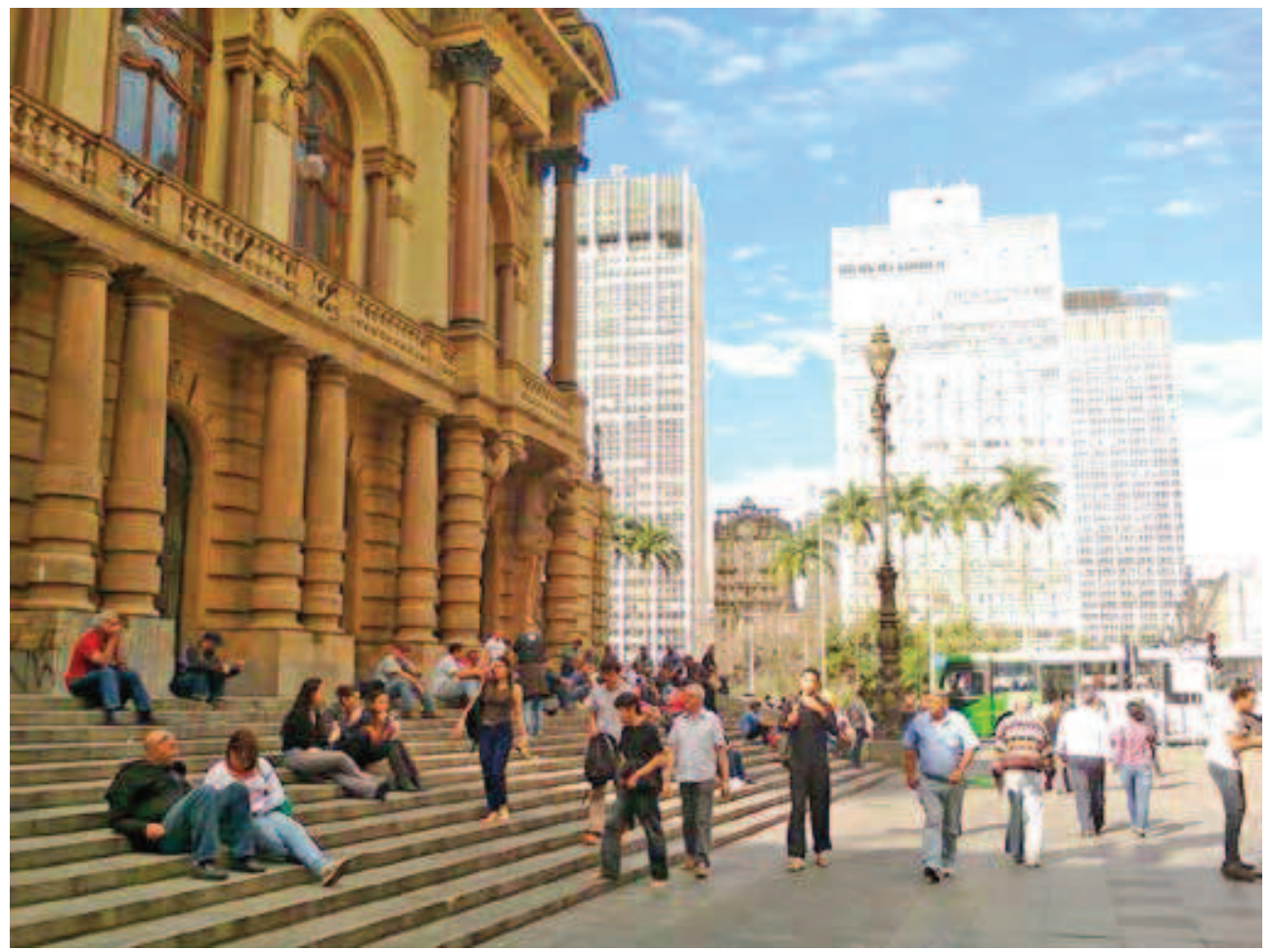

Figura 14 Escadaria do Theatro Municipal, na praça Ramos de Azevedo.

Foto: Lilian Dazzi Braga Rupf - 2014

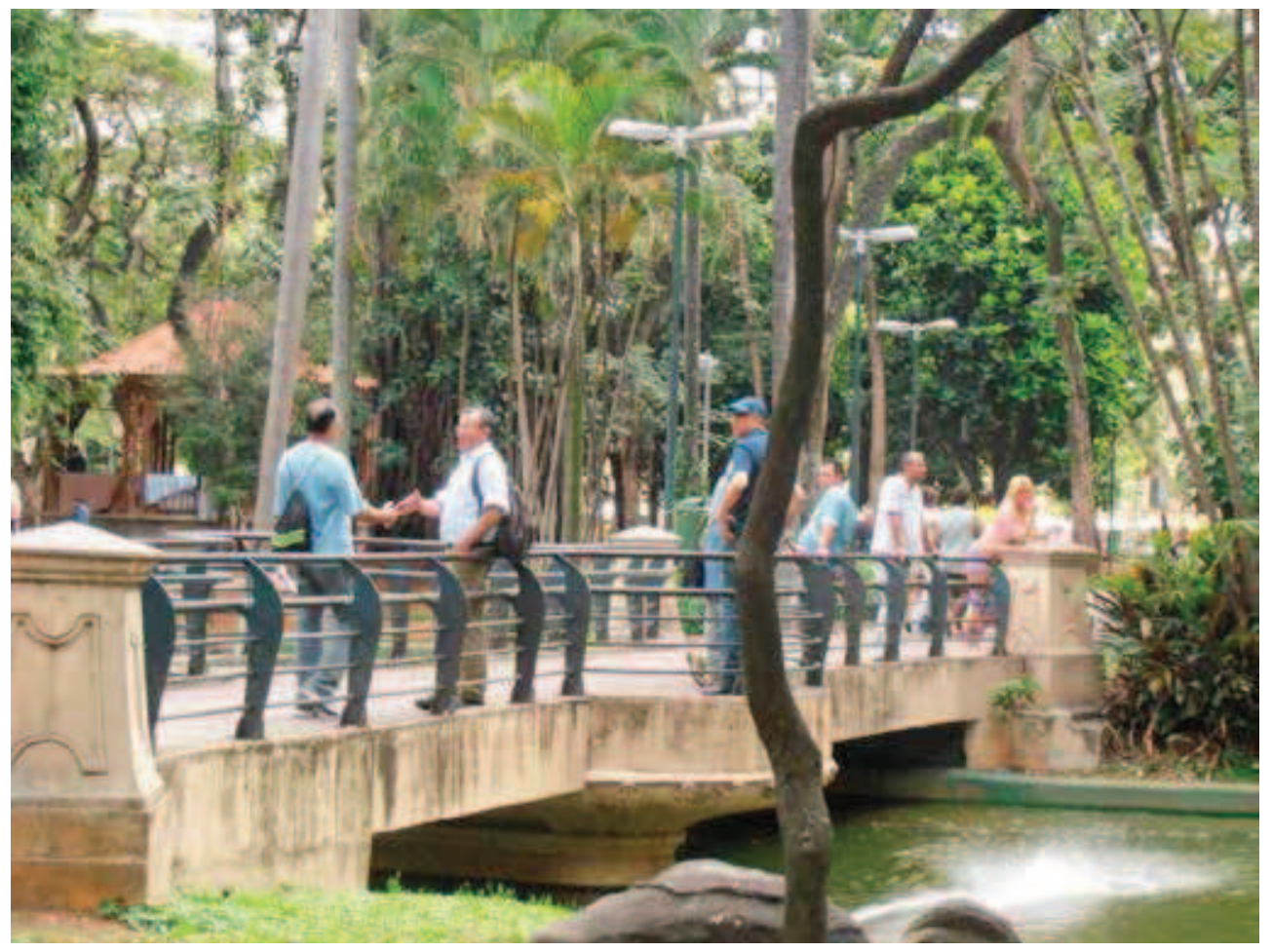

Figura 15 Pontes sobre espelhos d'água na praça da República. Foto: Lilian Dazzi Braga Rupf - 2013 
Os lugares públicos do centro se adaptaram às mudanças da cidade e de sua esfera de vida pública. Abrigam novas práticas, que ocorrem não apenas nos espaços de propriedade pública, mas também nos espaços complementares, de propriedade privada - como bares, cinemas e igrejas (figuras 16 a 20). A complexidade contemporânea desses lugares requer projetos que garantam acessibilidade, que sejam adaptáveis e potencializadores de eventos e manifestações coletivas, troca comunicacional e convívio com opostos:

Não se trata de um declínio inexorável dos centros, pois alguns se popularizaram mais, estando ainda mais vivos do que no período em que eram o espaço predileto das elites. Esses centros, com seus novos frequentadores e novas práticas espaciais, requerem políticas e projetos urbanos mais flexíveis e participativos, evitando ações de ordenamento espacial preconcebidas segundo padrões estéticos exógenos pouco atentos à realidade dos lugares públicos brasileiros. Com o aumento da população de renda médio-baixa no país, é desejável oportunizar lugares públicos capazes de contribuir para que tais classes de renda não sejam apenas novos consumidores, mas protagonizem transformações qualitativas no avanço da cidadania brasileira. (QUEIROGA, 2012, p. 227).

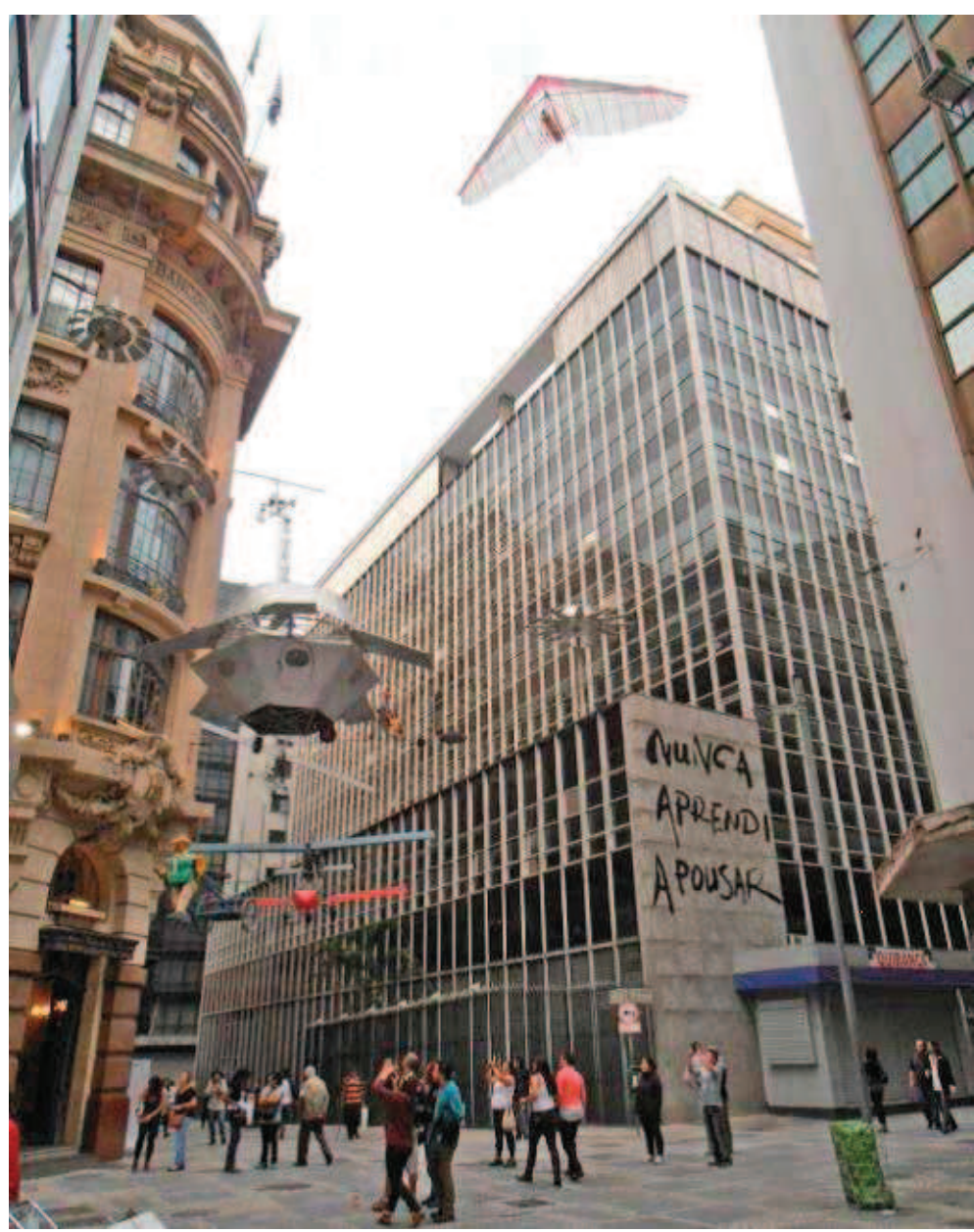

Figura 16 Exposição externa ao Centro Cultural Banco do Brasil (CBBB). Foto: Lilian Dazzi Braga Rupf - 2013 


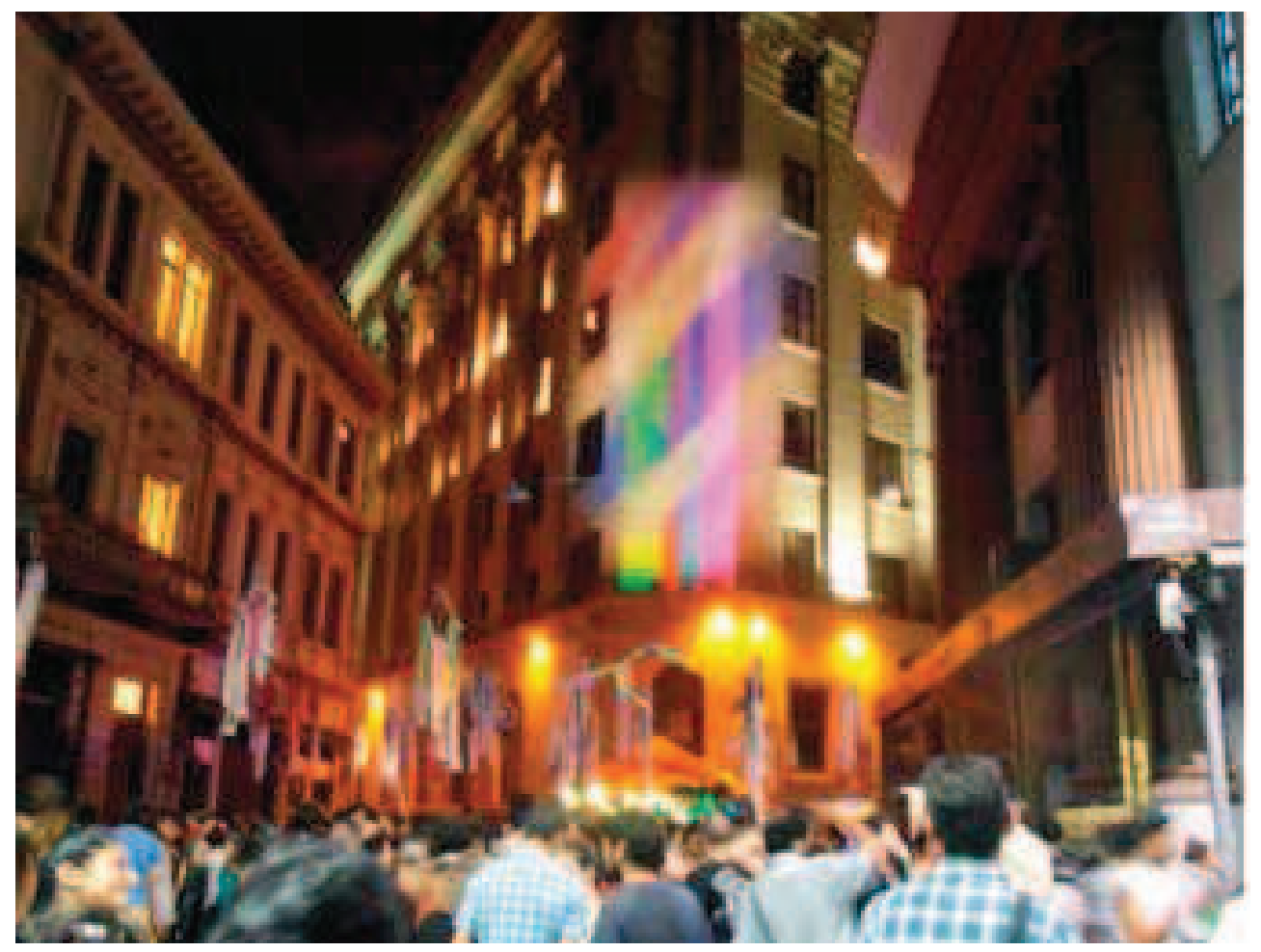

Figura 17 Evento SP na Rua, no largo do Café.

Foto: Lilian Dazzi Braga Rupf - 2014

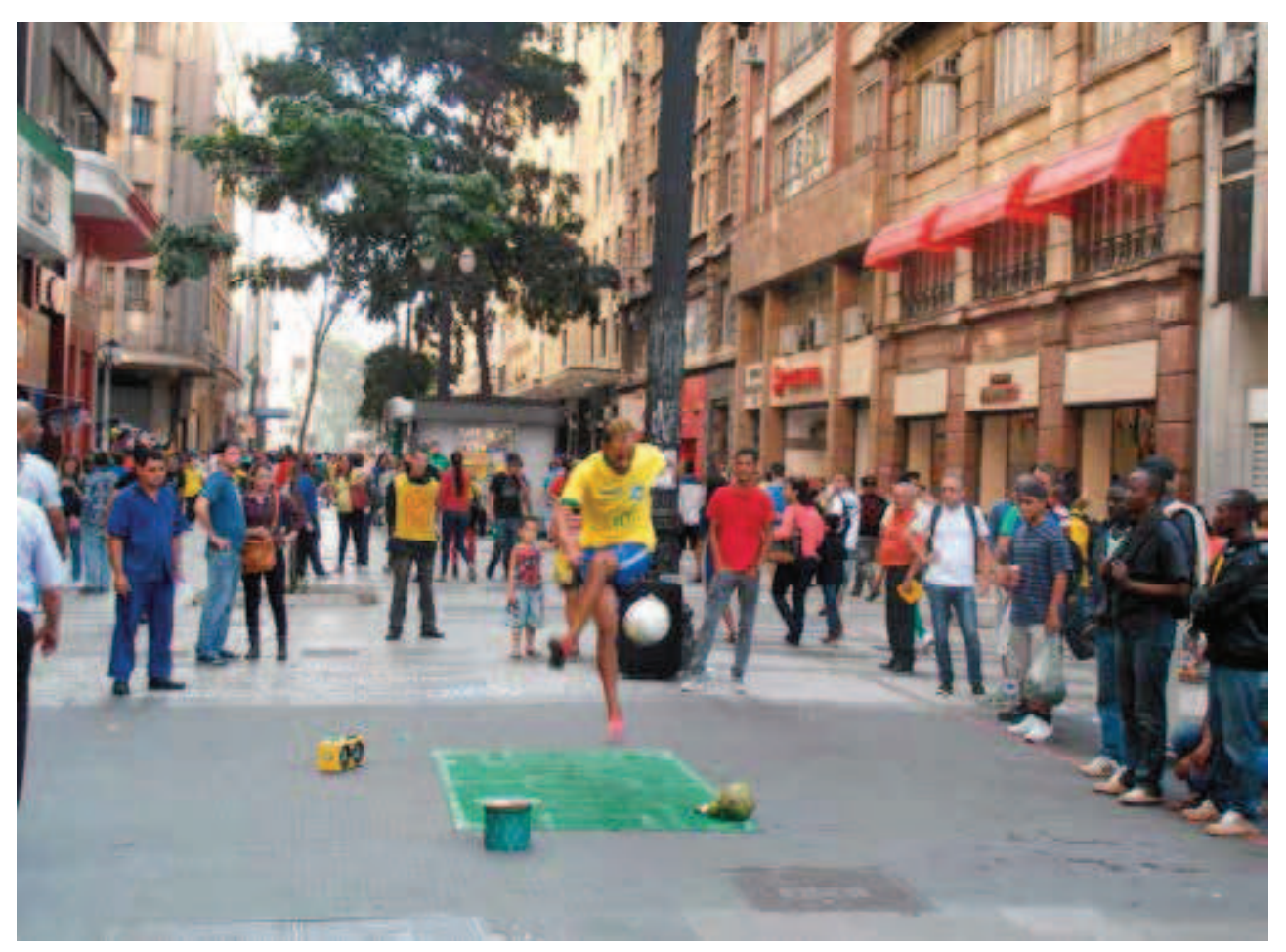

Figura 18 Artista de rua no calçadão da rua Barão de Itapetininga.

Foto: Lilian Dazzi Braga Rupf - 2014 


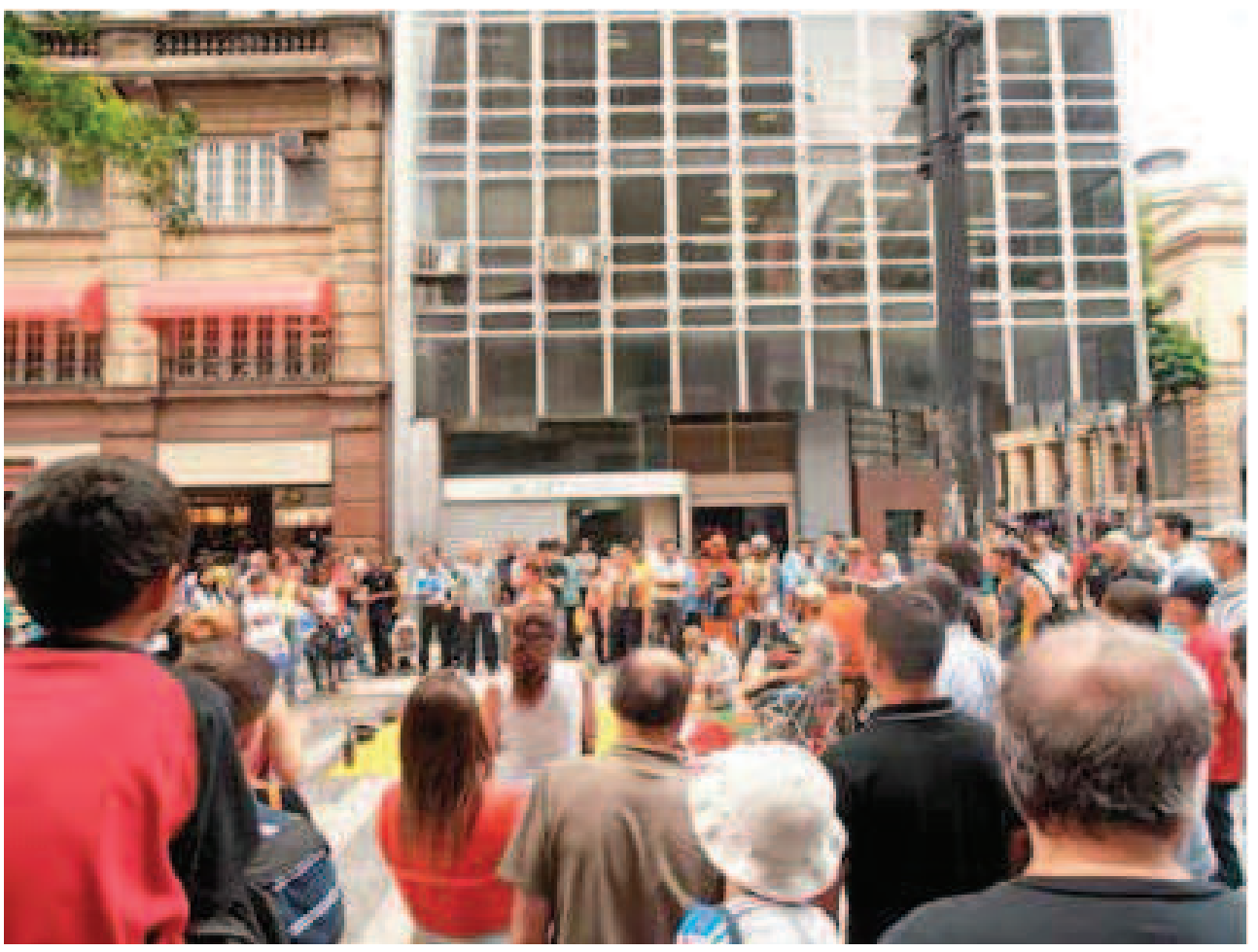

Figura 19 Banda na rua Barão de Itapetininga.

Foto: Lilian Dazzi Braga Rupf - 2014

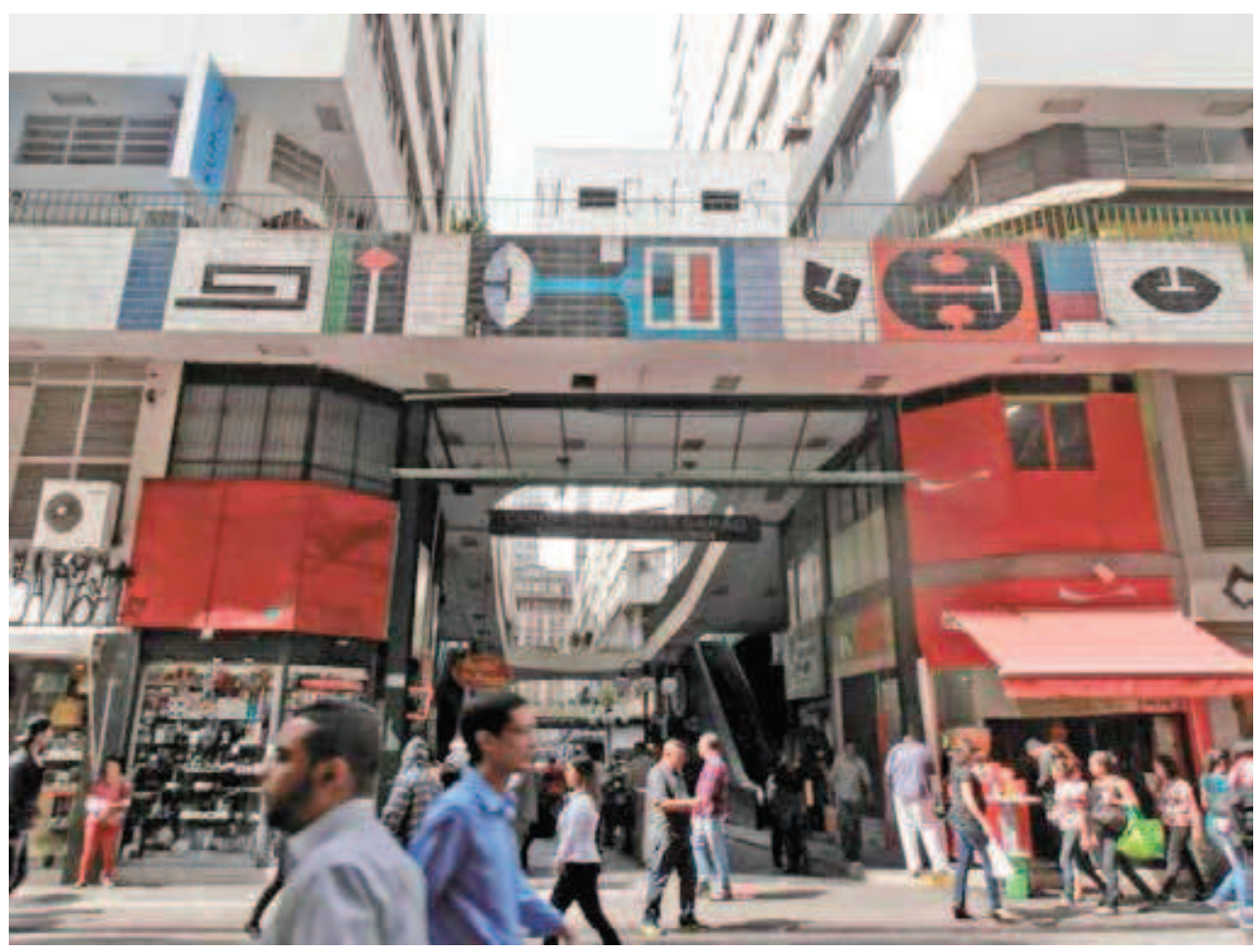

Figura 20 Rua 7 de Abril e acesso à galeria Nova Barão.

Foto: Lilian Dazzi Braga Rupf - 2014 


\section{CONSIDERAÇÕES FINAIS}

O Centro Histórico de São Paulo tem como legado urbano um sistema de espaços livres bem articulado, com espaços projetados ou reformulados durante o século XX. Vale lembrar a escala paulistana: 11 milhões de habitantes, ou 20 milhões, considerando sua região metropolitana. Mas, se evocarmos à memória outras metrópoles ou cidades médias brasileiras que conhecemos, teremos, na devida proporção, experiências próximas às descritas em seus centros (guardando individualidades e particularidades). Os lugares públicos centrais, muitas vezes sem intenção do projeto urbano ou paisagístico, são palcos de encontros, trocas, conflitos e manifestações políticas, mesmo sem a qualidade ambiental desejada.

Os lugares públicos estão em constante mudança enquanto práticas espaciais e usos. A observação de suas dinâmicas e complexidades deve buscar compreendê-los a fim de contribuir para a qualificação de seus espaços. Desse modo, pode-se fornecer subsídios para projetos, planos e políticas públicas em consonância com suas demandas, em busca de lugares democráticos, acessíveis e reprogramáveis, que favoreçam a inclusão e o encontro público.

\section{REFERÊNCIAS BIBLIOGRÁFICAS}

CARDOSO, Ruth. Identidade e convivências: o centro como ponto de encontro. In: HUET, Bernard et al. Os centros das metrópoles: reflexões e propostas para a cidade democrática do século XXI. São Paulo: Terceiro Nome, 2001 , p. 37-43.

FERRARA, Lucrécia D'Alessio. Os significados urbanos. São Paulo: Edusp/FAPESP, 2000. 185 p.

FRUGOLI JR., Heitor. Centralidade em São Paulo: trajetórias, conflitos e negociações na metrópole. São Paulo: Cortez/Edusp/FAPESP, 2000. 264 p.

MACEDO, Silvio Soares et al. Os sistemas de espaços livres na constituição da forma urbana contemporânea no Brasil: produção e apropriação. QUAPÁSEL II. Projeto temático de pesquisa coordenado pelo laboratório Quapá da Faculdade de Arquitetura e Urbanismo da Universidade de São Paulo, 2012.

NAKANO, Kazuo; CAMPOS, Candido Malta; ROLNIK, Raquel. Dinâmica dos subespaços na área central de São Paulo. In: COMIN, Alvaro A.; SOMEKH, Nadia (Orgs.). Caminhos para o centro: estratégias de desenvolvimento para a região central de São Paulo. São Paulo: PMSP/Cebrap/CEM, 2004, p. 123-158.

QUEIROGA, Eugenio Fernandes. Dimensões públicas do espaço contemporâneo: resistências e transformações de territórios, paisagens e lugares urbanos brasileiros. 2012. 284 f. Tese (Livre-docência em Arquitetura e Urbanismo) - Faculdade de Arquitetura e Urbanismo, Universidade de São Paulo, São Paulo, 2012.

REIS FILHO, Nestor Goulart. São Paulo: vila, cidade, metrópole. São Paulo: Prefeitura Municipal de São Paulo, 2004. $261 \mathrm{p}$.

RHEINGANTZ, Paulo. Narrativas ou traduções de urbanidades. In: NETTO, Vinicius M.; AGUIAR, Douglas A (Orgs.). Urbanidades. Rio de Janeiro: Folio Digital: Letra e Imagem, 2012, p. 135-161.

SANTOS, Milton. A natureza do espaço: técnica e tempo, razão e emoção (1996). São Paulo: Hucitec, $2012 a$. 392 p.

Espaço e método (1985). São Paulo: Edusp, 2012b. 120 p.

TOLEDO, Benedito Lima de. São Paulo: três cidades em um século (1981). São Paulo: Cosac Naify/Duas Cidades, 2007. 191 p.

VARGAS, Heliana C.; CASTILHO, Ana Luisa H (Orgs.). Intervenções em centros urbanos: objetivos, estratégias e resultados. Barueri: Manole, 2006. 289 p. 